\title{
Orofacial myofunctional evaluation in cleft lip and palate: an integrative literature review
}

Andréia Fernandes Graziani ${ }^{1}$ https://orcid.org/0000-0001-9802-7460

Giédre Berretin-Felix ${ }^{2}$ https://orcid.org/0000-0002-8614-2805

Katia Flores Genaro ${ }^{1,2}$ https://orcid.org/0000-0002-5218-760X

Hospital de Reabilitação de Anomalias Craniofaciais da Universidade de São Paulo - HRAC-USP, Bauru, São Paulo, Brasil.

2 Faculdade de Odontologia de Bauru, Universidade de São Paulo - FOB-USP, Bauru, São Paulo, Brasil.

Research support source: Coordination for the Improvement of Higher Education Personnel CAPES.

Conflict of interests: Nonexistent

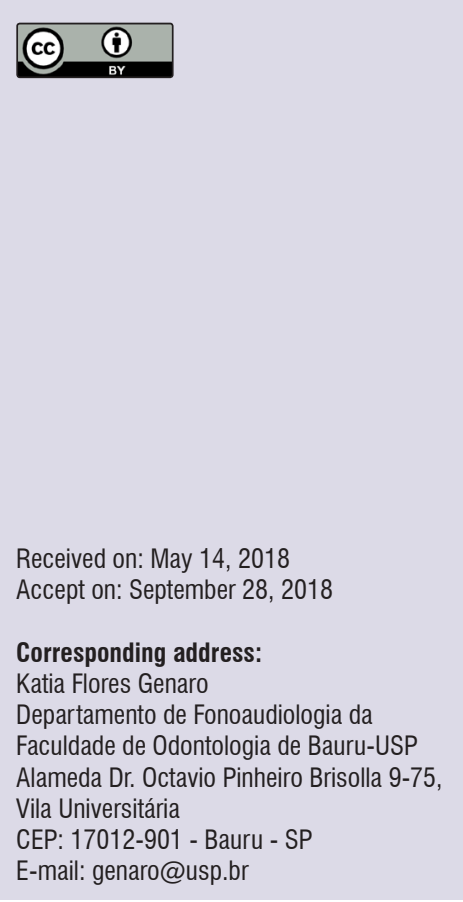

\section{ABSTRACT}

Purpose: to identify the focus of scientific publications in the field of orofacial motricity in individuals with cleft lip and palate, as well as validated protocols used in speech and language evaluation.

Methods: a study conducted using the following databases: Medline, SciELO, Lilacs and Google Scholar, through keywords including: cleft palate + cleft lip + evaluation + speech therapy + stomatognathic system + speech + phonation + chewing + swallowing + breathing + validation studies, in Portuguese and English.

Results: a total of 572 articles that addressed the evaluation of the stomatognathic system was selected. The articles were published between 2012 and 2017, and examined for year of publication, subject area, focus, instrument used for evaluation, and type of study. Of these, 90 articles met the inclusion criteria, but only 5 used validated protocols. The greatest number of articles was published in 2014. The studies covered broad age groups, using subjective and objective methods, and instruments were often non-standardized.

Conclusion: speech was the prevalent theme, while other orofacial functions were poorly investigated, demonstrating that studies with other approaches were lacking.

Keywords: Cleft Lip; Cleft Palate; Stomatognathic System; Evaluation; Speech, Language and Hearing Sciences; Validation Studies 


\section{INTRODUCTION}

The stomatognathic system consists of oral structures and performs several essential functions thatinterrelatewith its anatomy. Thus, any influence on this system will result in adaptation'. Cleft lip and palate affect the stomatognathic system and, consequently, the performance of orofacial functions.

Even after surgical correction, individuals may present with orofacial myofunctional changes that require speech therapy ${ }^{2}$. Thus, a detailed evaluation of the stomatognathic system ${ }^{3,4}$ is essential for the speech-language pathologist to diagnose and treat dysfunction. There is a need for a well-structured data collection and recording system, and for standardized evaluation protocols 5 .

Among the functions performed by the stomatognathic system, speech is altered by the presence of a cleft lip and palate.This contributes to further stigmatization of individuals with this malformation, which has beenwidely studiedin the literature. However, since the other components of this system are also important for achieving morpho-functional balance and completion of treatment, breathing, chewing, and swallowing functions should also be addressed. The question is whether all orofacial myofunctional components are being evaluated in individuals with cleft lip and palate.

Speech therapyhas emphasized the importance of evidence-based practice, and integrative review is a method that meets this objective, as it analyzes and synthesizes the results of selected studies, making them useful in bothclinical practice and scientific research. This type of review has several purposes: definition of concepts, revision of theories and evidence, andanalysis of methodological problems of a particular topic that allows the inclusion of experimental and non-experimental studies, in order to understand a specific subject ${ }^{6}$.
Therefore, this study aimed to identify the focus of scientific publications in the area of orofacial motricity in individuals with cleft lip and palate, as well as validated protocols used in speech therapy evaluation.

\section{METHODS}

This study was conducted using the following databases: Medline, SciELO, Lilacs, and Google Scholar, through keywords including: cleft palate + cleft lip + evaluation + speech therapy + stomatognathic system + speech + chewing + swallowing + breathing + validation studies, in Portuguese and English.

Articles published between 2012 and 2017 that addressed speech therapy evaluation with regard to aspects of the stomatognathic system in individuals with cleft lip and palate not associated with syndromes were selected. Articles that used any validated protocol and analysis regarding the level of scientific evidence were categorized. The titles, abstracts, and articles that met the inclusion criteria were read in full.

As a selection criterion, all literature review articles, clinical cases, monographs, theses, and books were excluded. The articles included in the study were analyzed by a single researcher and tabulated according to the following categories: year of publication, subject area, focus, instrument used for evaluation, type of study, study objective and results.

\section{LITERATURE REVIEW}

The database search identified 572 articles based on the title and abstract. Of these, 482 were excluded, 405 for not meeting the inclusion criteria and/or not involving speech therapy evaluations in orofacial motricity, and 77 due to duplication. Thus, 90 articles were included and analyzed in their entirety (Figure 1). 


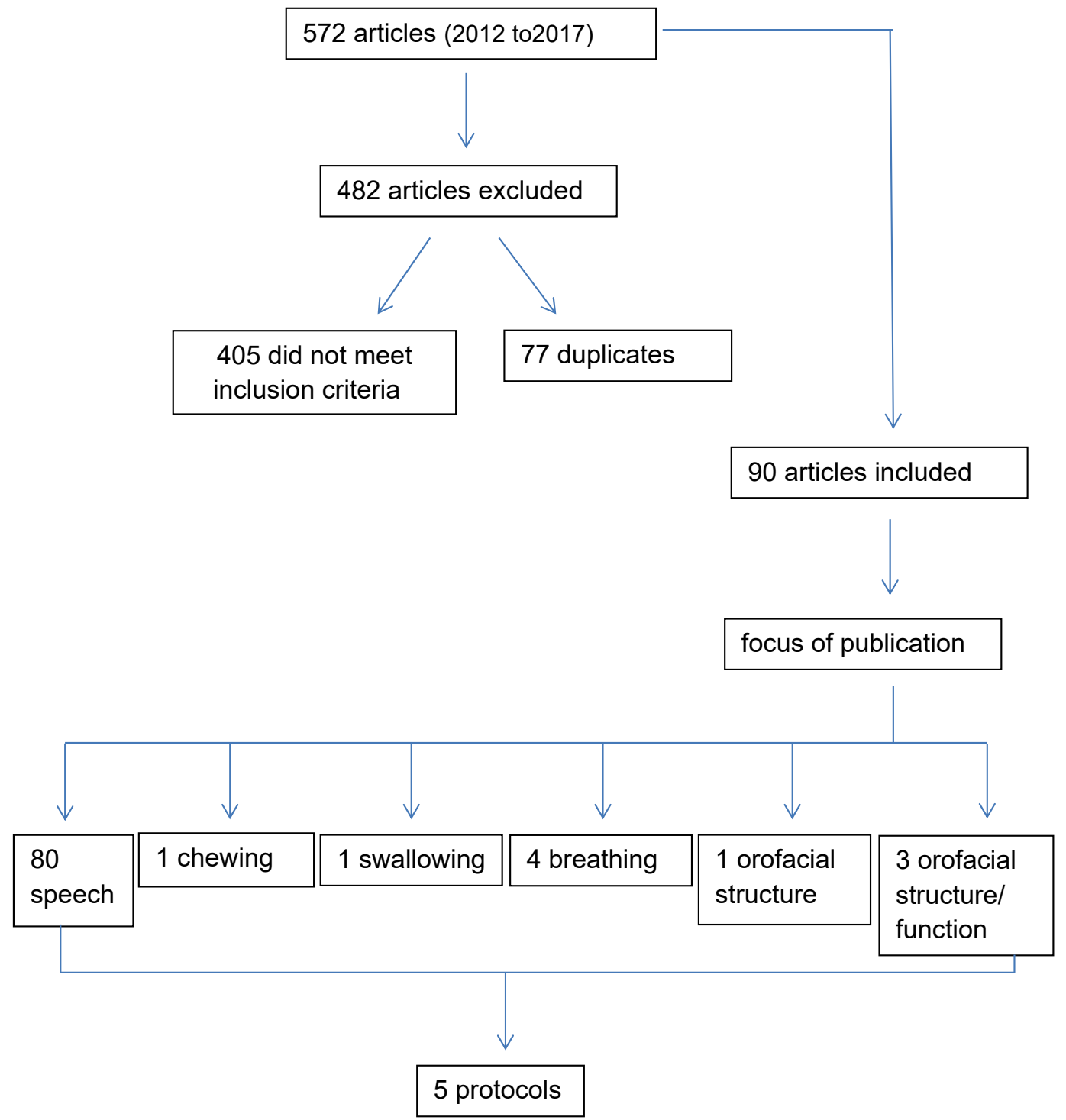

Figure 1. Steps of the literature review analysis process

The selected articles were grouped by category: year of publication, subject area, focus, instrument used for evaluation, type of study, study objective, and results. The articles were subsequently grouped according to the focus of study: $90 \%$ (80 articles) focused on the evaluation of speech, $1 \%$ ( 1 article) on chewing, $1 \%$ (1 article) on swallowing, $1 \%$ (1 article) on orofacial structures, $4 \%$ (4 articles) on breathing, and $3 \%$ (3 articles) on evaluation of orofacial structures and function (Figure 2). Figure 3 shows the distribution of articles according to the subject area, and the focus of the publications by date. 


\begin{tabular}{|c|c|c|c|c|c|c|c|}
\hline $\begin{array}{c}\text { Year of } \\
\text { Publication }\end{array}$ & Subject Area & $\begin{array}{l}\text { No. of } \\
\text { Articles }\end{array}$ & Focus & Evaluation Method & Type of Study & Objectives & Results \\
\hline $\begin{array}{l}2012 \text { to } \\
2017\end{array}$ & Speech & 80 & $\begin{array}{l}\text { - cleft lip and } \\
\text { palate } \\
\text { - solated cleft } \\
\text { palate } \\
\text { - broad age } \\
\text { group }\end{array}$ & $\begin{array}{l}\text { - perceptual-auditory } \\
\text { analysis } \\
\text { - instrumental exams: } \\
\text { - nasometry, } \\
\text { - nasoendoscopy, } \\
\text { - acoustic rhinometry, } \\
\text { - rhinomanometry, } \\
\text { - videofluoroscopy, } \\
\text { - electromyography }\end{array}$ & $\begin{array}{l}\text { - retrospective } \\
\text { - prospective } \\
\text { - descriptive } \\
\text { - qualitative } \\
\text { - quantitative }\end{array}$ & $\begin{array}{l}\text { - speech } \\
\text { evaluation } \\
\text { •therapy, } \\
\text { language and } \\
\text { velopharyngeal } \\
\text { function; } \\
\text { - speech results } \\
\text { after surgery }\end{array}$ & $\begin{array}{l}\text { - phonetic, phonological, and } \\
\text { velopharyngeal function-related } \\
\text { alterations; } \\
\text { - need for evaluation protocol and } \\
\text { training; } \\
\text { - effective pharyngeal flap and } \\
\text { veloplasty in the correction of } \\
\text { velopharyngeal dysfunction } \\
\text { - undefined best age and surgical } \\
\text { technique; } \\
\text { - subsidiary instrumental methods } \\
\text { for speech evaluation }\end{array}$ \\
\hline 2014 & Chewing & 1 & \begin{tabular}{|l|} 
- cleft lip and \\
palate \\
-7 to 14 \\
years old \\
-47 cases
\end{tabular} & $\begin{array}{l}\text { - chewing tests } \\
\text { - electromyography }\end{array}$ & $\begin{array}{l}\text { - prospective } \\
\text { - descriptive } \\
\text { - qualitative }\end{array}$ & \begin{tabular}{|l} 
- verify \\
concordance \\
between 3 \\
evaluation \\
methods and the \\
chewing pattern \\
in unilateral and \\
bilateral cleft \\
\end{tabular} & $\begin{array}{l}\text { - unilateral fissure with greater } \\
\text { amplitude of electromyographic } \\
\text { signal than bilateral; } \\
\text { - lack of agreement between } \\
\text { methods. }\end{array}$ \\
\hline 2015 & Swallowing & 1 & \begin{tabular}{|l|} 
- cleft lip and \\
palate \\
-0 to 3 years \\
old \\
-7 cases
\end{tabular} & $\begin{array}{l}\text { - clinical exam } \\
\text { - videofluoroscopy }\end{array}$ & $\begin{array}{l}\text { - prospective } \\
\text { - descriptive } \\
\text { - quantitative }\end{array}$ & $\begin{array}{l}\text { - evaluate } \\
\text { swallowing }\end{array}$ & $\begin{array}{l}\text {-choking, nasal regurgitation, and } \\
\text { failure of velopharyngeal function }\end{array}$ \\
\hline $\begin{array}{l}2013 \text { and } \\
2015\end{array}$ & Breathing & 4 & \begin{tabular}{|l} 
- cleft lip and \\
palate \\
-6 to 40 \\
years old
\end{tabular} & $\begin{array}{l}\text { - clinical exam } \\
\text { - respiratory symptom } \\
\text { questionnaire } \\
\text { - instrumental exams: } \\
\text { - videonasoendoscopy } \\
\text { - rhinomanometry } \\
\text { - acoustic rhinometry }\end{array}$ & $\begin{array}{l}\text { - retrospective } \\
\text { - prospective } \\
\text { - descriptive } \\
\text { - qualitative } \\
\text { - quantitative }\end{array}$ & $\begin{array}{l}\text { - evaluate } \\
\text { nasopharyngeal } \\
\text { dimensions } \\
\text { and respiratory } \\
\text { symptoms after } \\
\text { surgery }\end{array}$ & $\begin{array}{l}\text {-reduction of nasopharyngeal } \\
\text { dimension; } \\
\text {-presence of respiratory symptoms } \\
\text { after pharyngeal flap surgery in } \\
\text { older individuals }\end{array}$ \\
\hline 2015 & $\begin{array}{l}\text { Orofacial } \\
\text { Structures }\end{array}$ & 1 & $\begin{array}{l}\text { - cleft lip } \\
-10 \text { to } 20 \\
\text { years old } \\
-70 \text { cases }\end{array}$ & $\begin{array}{l}\text { - clinical exam } \\
\text { - nasoendoscopy }\end{array}$ & $\begin{array}{l}\text { - retrospective } \\
\text { - prospective } \\
\text { - quantitative }\end{array}$ & $\begin{array}{l}\text { - identify signs } \\
\text { of hidden } \\
\text { submucosal cleft } \\
\text { in individuals } \\
\text { with cleft lip and } \\
\text { without clinical } \\
\text { signs of cleft } \\
\text { palate }\end{array}$ & $\begin{array}{l}-15 \% \text { of cases with signs of hidden } \\
\text { submucosal fissure }\end{array}$ \\
\hline $\begin{array}{l}2012 \text { and } \\
2015\end{array}$ & $\begin{array}{l}\text { Orofacial } \\
\text { Structure/ } \\
\text { Function }\end{array}$ & 3 & $\begin{array}{l}\text { - cleft lip and } \\
\text { palate } \\
-7 \text { to } 28 \\
\text { years old }\end{array}$ & - clinical exam & $\begin{array}{l}\text { - retrospective } \\
\text { - prospective } \\
\text { - descriptive } \\
\text { - qualitative } \\
\text { - quantitative }\end{array}$ & $\begin{array}{l}\text { - evaluate } \\
\text { influence of the } \\
\text { short frenulum on } \\
\text { speech; } \\
\text { - elaborate a } \\
\text { myofunctional } \\
\text { evaluation } \\
\text { protocol applied } \\
\text { to the cleft, and } \\
\text { carry out content } \\
\text { validation; } \\
\text { - investigate } \\
\text { speech and } \\
\text { myofunctional } \\
\text { alterations }\end{array}$ & $\begin{array}{l}\text { - without influence on speech, but } \\
\text { on mobility; } \\
\text { - a protocol was developed with } \\
\text { structural and functional aspects } \\
\text { of the stomatognathic system, and } \\
\text { the content was validated; } \\
\text { - presence of compensatory, } \\
\text { compulsory and phonological } \\
\text { disorders; } \\
\text { - change in tonicity, mobility } \\
\text { (tongue, lips and cheeks), habitual } \\
\text { posture (tongue and lips) and } \\
\text { occlusion }\end{array}$ \\
\hline
\end{tabular}

Figure 2. Distribution of articles according to subject area 


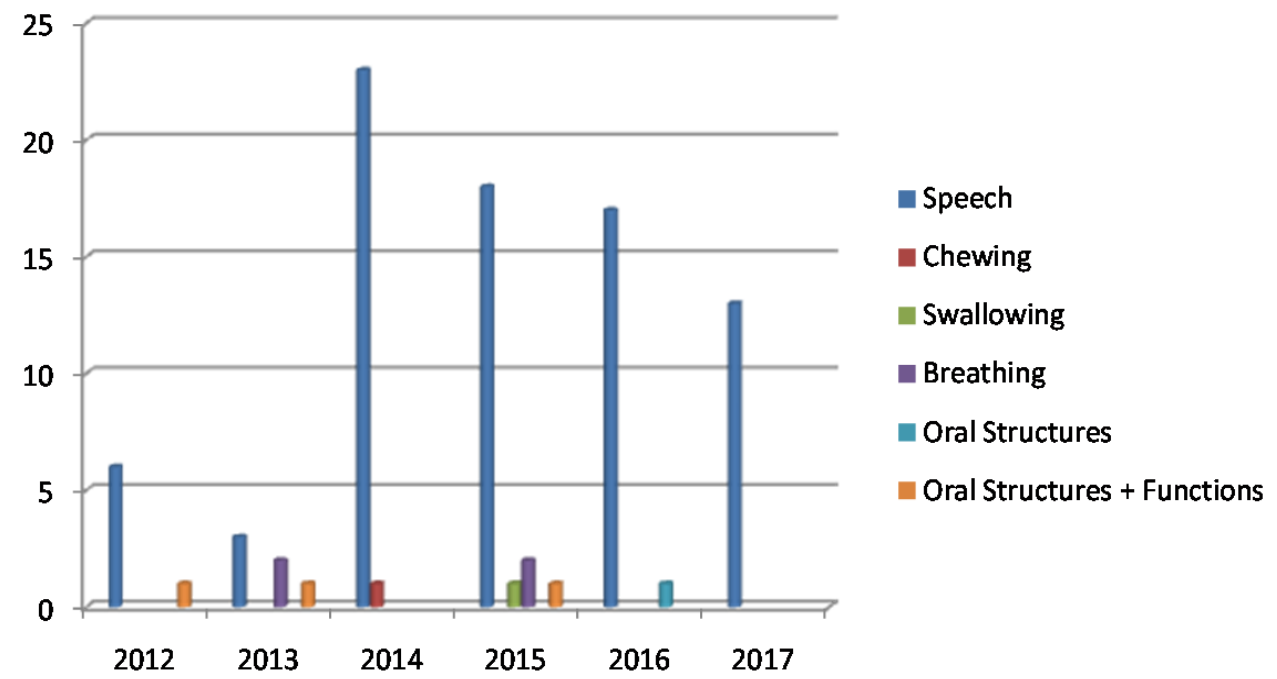

Figure 3. Distribution of research articles according to the subject area and time period

Out of 80 studies (100\%) that considered speech, $26(32 \%)$ referred to articulation, 21 (26\%) to results after surgical procedures, $2(3 \%)$ to results according to different surgical techniques, $4(5 \%)$ to speech and language, $2(3 \%)$ to results after speech therapy, and $25(31 \%)$ to speech and evaluation of velopharyngeal function.

This review indicated that speech was the most discussed topic. This is understandable, since individuals with a speech impairment may be devalued by society due to their impaired ability to converse. In addition, speech challenges can influence individuals in other ways, and may be associated with emotional and/ or psychological problems, such as low self-esteem, anxiety, and depression ${ }^{7}$, thus affecting quality of life in those with cleft lip and palate ${ }^{8}$.

Individuals with cleft lip and palate need repair surgery aimed at anatomical and functional correction, and studies have attempted to identify the optimal timing of surgery, as well as to define the best surgical technique ${ }^{9,10}$. However, surgical failures may occur due to factors such as surgical technique and skill, cleft palate width, and/or inadequate postoperative care ${ }^{11}$. Secondary surgical procedures on the palate may be necessary, mainly to provide adequate velopharyngeal function. When the velopharyngeal mechanism fails, a gap or communication between the nasal and oral cavities results invelopharyngeal dysfunction (VPD). This can be caused by a lack of tissue (velopharyngeal insufficiency) or by an alteration in the mobility of structures (velopharyngeal incompetence) ${ }^{12}$. The effect on speech presents as compensatory articulation, hypernasality, nasal air leakage, weak intraoral pressure, and nasal turbulence ${ }^{13}$.

These findings explain the prevalence of the focus on speech in the articles analyzed. Among the selected studies, 74 used perceptual-auditory evaluation in speech analysis. The literature reports that this method is the most used by speech therapists for speech analysis, and is considered the gold standard ${ }^{14,15}$. However, it is a subjective method, and depends on the experience and training of the listener ${ }^{16}$. Therefore, complementary examinations are suggested to verify the reliability of the results. Complementary instrumental exams, such as nasometry, nasoendoscopy, rhinomanometry, acoustic rhinometry, videofluoroscopy, and electromyography, were identified in this literature review.

Only 5 articles used validated evaluation protocols; only 1 referred to a proposal for an orofacial myofunctional evaluation protocol, while the others used existing evaluation protocols. The other 4 studies used the Cleft Audit Protocol for Speech-Augmented (CAPS-A $)^{17}$, which is considered a reliable, valid, and acceptable speech audit toolin individuals with cleft lip and palate. Used inthe UK and Ireland, and recently by the Americleft group ${ }^{18}$, it evaluates 8 parameters of speech: intelligibility, hypernasality, hyponasality, voice, nasal air leakage, nasal turbulence, facial mimicry, and articular changes characteristic of cleft lip and palate, aimingto standardize evaluation and enable sharing of the results with other institutions ${ }^{19}$.

Using the the selected articles, the characteristics of studies that presented validated evaluation protocols were analyzed (Table 1). 
Table 1. List of selected articles that presented evaluation protocols in their methodology

\begin{tabular}{|c|c|c|c|c|c|}
\hline JOURNAL & $\begin{array}{c}\text { YEAR OF } \\
\text { PUBLICATION }\end{array}$ & AUTHORS & FOCUS & $\begin{array}{l}\text { EVALUATION } \\
\text { PROTOCOL }\end{array}$ & $\begin{array}{l}\text { LEVEL OF } \\
\text { EVIDENCE }\end{array}$ \\
\hline $\begin{array}{l}\text { Cleft Palate- } \\
\text { Craniofacial Journal }\end{array}$ & 2014 & Britton L et al. & $\begin{array}{c}\text { CLP/CP } \\
\text { (5 years old) }\end{array}$ & CAPS-A & 3 \\
\hline CoDAS & 2015 & $\begin{array}{l}\text { Graziani AF, } \\
\text { Fukushiro AP, } \\
\text { Genaro KF }\end{array}$ & $\begin{array}{c}75 \text { CLP } \\
\text { (7 and } 29 \text { years old) }\end{array}$ & CLEFT PROTOCOL & 4 \\
\hline $\begin{array}{l}\text { Cleft Palate- } \\
\text { Craniofacial Journal }\end{array}$ & 2016 & Chapman KL et al. & $\begin{array}{l}19 \text { CLP/CP } 1 \text { VPD } \\
\text { (5 and } 10 \text { years old })\end{array}$ & CAPS-A & 4 \\
\hline $\begin{array}{l}\text { Orthodontics } \\
\text { \& Craniofacial } \\
\text { Research }\end{array}$ & 2017 & Sell D et al. & $\begin{array}{c}268 \mathrm{CLP} \\
\text { (5 years old) }\end{array}$ & CAPS-A & 2 \\
\hline $\begin{array}{l}\text { Cleft Palate- } \\
\text { Craniofacial Journal }\end{array}$ & 2017 & $\begin{array}{c}\text { Castick S, Knight } \\
\text { RA, Sell D }\end{array}$ & 25 CLP & CAPS-A & 3 \\
\hline
\end{tabular}

Legend: CLP = Cleft Lip and Palate; $C P=$ Cleft Palate; VPD = Velopharyngeal Dysfunction; CAPS-A = Cleft Audit Protocol for Speech-Augmented

Data on the articles presented in Table 1.

\section{Britton, Albery, Bowden et al..$^{20}$ :}

Parameters for the analysis of speech and treatment results were established in 12 centers in Great Britain and Ireland, aiming at a national audit process to standardize the records of individuals with cleft lip and palate, and to improve treatment. This observational, cohort, prospective, qualitative study, with level of evidence 3 , was split into 2 phases, and 1,110 speech samples were selected from children with cleft lip and palate born between 2001 and 2006. Samples were analyzed by speech therapists experienced in the application of the CAPS-A protocol ${ }^{17}$ to determine the optimal timing of speech evaluation and recording and to compare inter-center speech results according to established parameters: speech evaluation (2 and 5 years old), speech and surgery, and surgery and hearing. The results showed flaws in the standardization of evaluations and data recording. However, it was found that $48 \%$ of children had normal speech, $66 \%$ did not have difficulties in speech development, and $60 \%$ did not have compensatory articulation. This study enabled a revision of national speech therapy protocols, as well as modification of evaluation and treatment parameters, thus improving the ability to compare results for use in clinical practice, and to enhance the quality of life in this population.

\section{Chapman, Baylis, Trost-Cardamone ${ }^{18:}$}

The reliability of inter- and intra-rater speech results was compared in 2 studies using the CAPS-A17 protocol in British and American-Canadian English. This was a cross-sectional, prospective, qualitative, observational study, with level of evidence 4. Ten speech samples were selected from 5 and 10-year-old children with cleft lip and palate, and 9 examiners were invited to analyze them. British samples were analyzed in 3 phases: 1) before training, 2) immediately after training, and 3) one month after training; American samples were analyzed 4 to 5 months after the evaluations for subsequent comparison. Results suggested that the classification of speech results was reliable, but the study demonstrated a lack of uniformity for all analyzed parameters, which justifies prior systematic training, to ensure acceptable levels of reliability.

\section{Graziani, Fukushiro, Genaro ${ }^{21}$ :}

This was an observational, transversal, prospective, qualitative study, with level of evidence 4. The authors developed and validated the content of a protocol entitled "Orofacial Myofunctional Evaluation for Individuals with Cleft Lip and Palate." A total of 75 individuals of both sexes with cleft lip and palate, ranging in age from 7 to 29 years old, participated in the study and were divided into 3 life-stages, i.e., childhood, adolescence, and adult life, in order to verify the applicability of the protocol. Content validation was performedusing expert opinions, as well as by the Content Validity Index, and a proposal for evaluation involving structural and functional aspects of the stomatognathic system was developed. However, the study did not use a control group to characterize 
orofacial myofunctional changes or treatment results after interventions. Moreover, the protocol wasnot validated in its entirety.

\section{Sell et al. ${ }^{22}$ :}

Speech results and interventions performed in 5-year-old children with cleft lip and palate seen at specialized centers in the UK were evaluated. The CAPS- ${ }^{17}$ protocol was used to evaluate the following parameters: articulation, intelligibility, velopharyngeal function, and presence of fistula. These were associated with factors such as hearing loss, speech therapy, secondary surgery, and socio-demographic and parental factors. This was an observational, crosssectional, prospective, quantitative study, with level of evidence 2. Results demonstrated variations in speech results among the different centers in the UK. The authors observed variation in the treatment of velopharyngeal insufficiency, which indicates the importance of treatment management and early speech therapy intervention. Because this was a multicenter study, there was a great deal of variability in the interventions and a lack of standardization in evaluation, despite use of the same protocol, which probably affected the results. Some factors werenot controlled, such as the choice of a single surgeon, age ofreparative surgery, and surgical technique.

\section{Castick, Knight, Sell ${ }^{19}$ :}

The reliability of the Visual Analogue Scale (VAS), when compared to an ordinal scale, was investigated in order to classify perceptual judgments of 6 speech parameters in individuals with cleft lip and palate: hypernasality, hyponasality, nasal leakage, nasal turbulence, intelligibility, and acceptability. This was an observational, transversal, prospective, quantitative study, with level of evidence 3 . Speech therapists trained in the use of ordinal scales, CAPS- $\mathrm{A}^{17}$ protocol guides, and universal parameters ${ }^{23}$ were invited to analyze 25 speech samples from individuals with cleft lip and palate. After hearing the samples, they classified them separately, using an ordinal scale and the VAS. Results showed that both scales are reliable instruments for all parameters evaluated. However, the use of these scales requires prior training, and the value range of the VAS may generate more subjectivity, when compared to the ordinal scale.

Although a standardized and validated protocol was generally not used for speech evaluation in the 75 remaining articles, $78 \%$ (58 articles) used perceptualauditory evaluation, $9 \%$ (7 articles) used existing evaluation protocols, and 13\% (10 articles) did not clarify the evaluation method used. It was found that $50 \%$ ( 40 articles) used complementary examinations for speech evaluation.

Of the 90 articles included in the study, $37 \%$ had diagnosis as their main goal, with a focus on prognosis in $63 \%$. One study ${ }^{24}$ evaluated speech intelligibility after primary palatoplasty in 12-month-old children with cleft lip and palate and verified that surgical intervention demonstrated satisfactory results for speech. Of the speech samples analyzed, $76 \%$ showed good intelligibility, $14 \%$ acceptable intelligibility, and $10 \%$ poor intelligibility.Another study ${ }^{25}$ evaluated the presence of hypernasality after surgical correction of the secondary palate, and the results showed a reduction of hypernasality in $75 \%$ of cases and elimination in $32 \%$. Of the selected studies, $90 \%$ used the judgment of experienced examiners, and $7 \%$ of lay examiners. According to the literature ${ }^{19,26}$, the use of reference and training models improves the reliability of the analysis. Crosssectional study modelswere prevalent (95\%), and only 1 article ${ }^{27}$ presented a randomized clinical study to verify the results of facial and speech development during the mixed dentition phase in individuals submitted to 2 different treatment protocols for correction of unilateral cleft lip and palate. Results showed small differences between the 2 protocols (Millard technique combined with nasal correction and Millard technique combined with nasal correction andanterior palate closure) and speech results. One of the groups showed potentially better development, while the other showed better speech results. However, neither protocol was considered superior. In $33 \%$ of the publications, the methodology and design of the study were not well defined, which highlights the need to improve the scientific methodin order to enable reproducibility. The articles covered broad age groups, and complete cleft lip and palate was the most studied subject. Speech was the focus of the publications in this study period, and other orofacial functions, such as chewing, swallowing, and breathing, as well as orofacial structures such as the lips, tongue, cheeks, teeth, hard palate, soft palate, uvula, and pharyngeal walls, were poorly investigated.

Thus, studies are needed to evaluate these other aspects, as well as other orofacial functions, since changes in the morphology of the stomatognathic system present with functional manifestations. Care 
standards for this population require improvement. Standardized collection and recording ofevaluation results are needed,in addition to validated protocols and systematic training in their use. Therefore, new studies that consider all aspects of orofacial myofunctional evaluation with greater methodological rigor are necessary.

\section{CONCLUSION}

In the last 5 years, there has been an important increase in scientific production in the field of orofacial motricity in cleft lip and palate cases. However, speech is the prevalent theme, probably because it is the cause of greatest stigma in these individuals. On the other hand, the evaluation of other orofacial functions is still lacking despite its importance in diagnosis and in defining the overall rehabilitation process. Moreover, standardized protocols are rarely used.

\section{REFERENCES}

1. Gonçalves LPV, Toledo OA, Otero SAM. Relação entre bruxismo, fatores oclusais e hábitos bucais. Dental Press J Orthod. 2010;15(2):97-104.

2. Lohmander A, Persson C. A longitudinal study of speech production in swedish children with unilateral cleft lip and palate and two-stage palatal repair. Cleft Palate Craniofac J. 2008;45(1):32-41.

3. Silva RN, Santos EMNG. Ocorrência de alterações de motricidade oral e fala em indivíduosportadores de fissuralabiopalatinas. RBPS. 2004;17(1):27-30.

4. Figueiredo MC, Pinto NF, Faustino-Silva DD, Oliveira M. Fissura bilateral completa de lábio e palato: alteraçõesdentárias de máoclusão - relato de caso clínico. UEPG: Ciências Biológicas e da Saúde. 2008;14(1):7-14.

5. Sell D, John A, Harding-Bell A, Sweeney T, Hegarty F, Freeman J. Cleft Audit Protocol for Speech (CAPS-A): a comprehensive training package for speech analysis. Int $\mathrm{J}$ Lang Commun Disord. 2009;44(4):529-48.

6. Souza MT, Silva MD, Carvalho R. Revisão integrativa: o que é e como fazer? Einstein. 2010;8(1):102-6.

7. Dzioba A, Skarakis-Doyle E, Doyle PC, Campbell W, Dykstra AD. A comprehensive description of functioning and disability in children with velopharyngeal insufficiency. J Commun Disord. 2013;46(4):388-400.
8. Tsangaris E, Riff KWYW, Goodacre T, Forrest CR, Dreise $\mathrm{M}$, Sykes $\mathrm{J}$ et al. Establishing content validity of the CLEFT-Q: a new patient-reported outcome instrument for cleft lip/palate. Plast Reconstr Surg Glob Open. 2017;5(4):e1305.

9. Sommerlad BC. International confederation for cleft lip and palateand related craniofacial anomalies task force report: palatoplasty in the speaking individual with unrepairedcleftpalate. CleftPalate Craniofac J. 2014;51(6):e122-8.

10. Dissaux C,Grollemund B, Bodin F, Picard A, Vazquez MP, Morand $B$ et al. Evaluation of 5-year-old children with complete cleft lip and palate: Multicenter study. Part 2: Functional results. J Craniomaxillofac Surg. 2016;44(2):94-103.

11. Smith DM, Losee JE. Cleft palate repair. Clin Plast Surg. 2014;41(2):189-210.

12. Kummer AW. Speech evaluation for patients with cleft palate. Clin Plast Surg. 2014;41(2):241-51.

13. Sie KCY, Tampakopoulou DA, Sorom JBA, Gruss JS, Eblen LE. Results with Furlow palatoplasty in management of velopharyngeal insufficiency. Plast Reconstr Surg. 2001;108(1):17-25.

14. Kuehn D, Moller K. Speech and language issues in the cleft palate population: the state of the art. Cleft Palate Craniofac J. 2000;37(4):348-83.

15. Kummer AW, Clark SL, Redle EE, Thomsen LL, Billmire DA. Current practice in assessing and reporting speech outcomes of cleft palate and velopharyngeal surgery: a survey of cleft palate/ craniofacial professionals. Cleft Palate Craniofac J. 2012;49(2):146-52.

16. Lewis KE, Watterson TL, Houghton SM. The influence of listener experience and academic training on ratings of nasality. $\mathrm{J}$ Commun Disord. 2003;36(1):49-58.

17. John A, Sell D, Sweeney T, Harding-Bell A, Williams A. The cleft audit protocol for speech-augmented: a validated and reliable measure for auditing cleft speech. Cleft Palate Craniofac J. 2006;43(3):272-88.

18. Chapman KL, Baylis A, Trost-Cardamone J, Cordero KN, Dixon A, Dobbelsteyn $C$ et al. The Americleft Speech Project: a training and reliability study. Cleft Palate Craniofac J. 2016;53(1):93-108.

19. Castick S, Knight RA, SellD. Perceptual judgments of resonance, nasal airflow, understandability, and acceptability in speakers with cleft palate: ordinal versus visual analogue scaling. Cleft Palate Craniofacial J. 2017;54(1):19-31. 
20. Britton L, Albery L, Bowden M, Harding-Bell A, Phippen G, Sell D. A cross-sectional cohort study of speech in five-year-olds with cleft palate +/- lip to support development of national audit standards: benchmarking speech standards in the United Kingdom. Cleft Palate Craniofacial J. 2014;51(4):431-51.

21. Graziani AF, Fukushiro AP, Genaro KF. Proposal and content validation of an orofacial myofunctional assessment protocol for individuals with cleft lip and palate. CoDAS. 2015;27(2):193-200.

22. Sell D, Southby L, Wren Y, Wills AK, Hall A, Mahmoud $O$ et al. Centre-level variation in speech outcome and interventions, and factors associated with poor speech outcomes in 5-year-old children with non-syndromic unilateral cleft lip and palate: The Cleft Care UK study. Part 4. Orthod Craniofac Res. 2017;20(2):27-39.

23. Henningsson G, Kuehn DP, Sell D, Sweeney T, Trost-Cardamone JE, Whitehall TL. Universal parameters for reporting speech outcomesin individuals with cleft palate. Cleft Palate Craniofac J. 2008;45(1):1-17.

24. Andreoli ML, Yamashita RP, Trindade-Suedam IK, Fukushiro AP. Speech intelligibility after primary palatoplasty: listener perception. Audiol Commun Res. 2016;21:e1650.

25. Yamashita RP, Silva ASC, Fukushiro AP, Trindade IEK. Perceptual and nasometric assessment of hypernasality after intravelarveloplasty for surgical management of velopharyngeal insufficiency: long-term effects. Rev. CEFAC. 2014;16(3):899-906.

26. Oliveira ACASF, Scarmagnani RH, Fukushiro AP, Yamashita RP. The influence of listener training on the perceptual assessment of hypernasality. CoDAS. 2016;28(2):141-8.

27. Ganesh P, Murthy J, Ulaghanathan N, Savitha VH. A randomized controlled trial comparing two techniques for unilateral cleft lip and palate: growth and speech outcomes during mixed dentition. J Craniomaxillofac Surg. 2015;43(6):790-5. 